\title{
Projection of phase composition of lowcost titanium alloy welded joints by finite element mathematical modeling method
}

\author{
Olena Gumen ${ }^{1}$, Irina Selina ${ }^{2}$, Roman Selin ${ }^{3}$ \\ ${ }^{1,2}$ National Technical University of Ukraine \\ «lgor Sikorsky Kyiv Polytechnic Institute», Kyiv, Ukraine \\ ${ }^{3}$ The E.O. Paton Electric Welding Institute of NASU, Kyiv, Ukraine \\ 1 gumens@ukr.net, orcid.org/0000-0003-3992-895X \\ 2irinaselina2016@gmail.com, orcid.org/0000-0002-1822-282X \\ 3selinrv@gmail.com
}

DOI: $10.32347 / 2310-0516.2019 .12 .51-56$

\begin{abstract}
Titanium as a structural material has a good set of mechanical and operational properties, allowing it to be used in various industries. One of the factors constraining the widespread use of titanium alloys is the high cost of titanium parts, which is associated with the technology of their manufacture and a relatively high cost of the raw materials used. The most promising in terms of price-reducing is the creation of economically alloyed alloys with improved processability since for titanium the cost of manufacture accounts for most of the total cost of parts. When producing welded joints of such alloys by fusion welding, there are due to the high content of alloying elements in them, the crystalline structure of the $\beta$-phase of titanium and the tendency to develop chemical and physical heterogeneity in the weld metal and the HAZ. This work presents a method of phase composition prediction in the welded joint via finite element modeling. As an example, we are using lowcost titanium alloy Timetal LCB. The paper includes the calculation of thermophysical properties, such as specific heat. To calculate the effect of welding mode parameters on the formation of a weld, a three-dimensional mathematical model of thermal processes in titanium was built for welding with a scanning heat source, which is based on the differential heat equation. Adequacy of the developed model is confirmed by experimental data. The depth and width of seam metal and HAZ, cooling speeds and phase composition are calculated.
\end{abstract}

Keywords. Finite element modeling; thermal processes; welding.

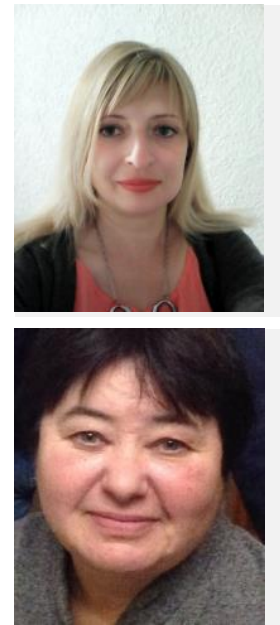

\section{Olena Gumen}

Professor; Department of Descriptive Geometry; Engineering and Computer Graphics

DSc; prof.

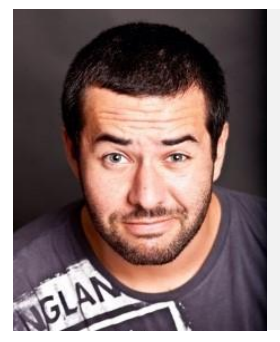

Irina Selina

Senior Lecturer; Department of Descriptive Geometry; Engineering and Computer Graphics

\section{Roman Selin}

Senior Researcher

$\mathrm{PhD}$

\section{INTRODUCTION}

Titanium as a structural material has a good set of mechanical and operational properties; allowing it to be used in various industries. One of the factors constraining the widespread use of titanium alloys is a high cost of titanium parts; which is associated with the technology of their manufacture and a relatively high cost of the raw materials used. Reducing the cost of products involves the development of alloys 
using cheap raw materials and such technological processes that provide higher efficiency in the use of consumed energy and materials. The most promising in terms of price reducing is the creation of economically alloyed alloys with improved processability; since for titanium the cost of manufacture accounts for most of the total cost of parts. In recent years; lowcost alloyed titanium alloys are becoming more common; in which expensive alloying elements are replaced by inexpensive and accessible elements; such as iron; carbon; oxygen and nitrogen [1-3].

\section{RESEARCH METHODS}

For this research; an economically alloyed Timetal LCB alloy doped with cheap eutectoidforming elements (i.e. iron in an amount of 4.5\%) was chosen (Table 1) [4].

This alloy belongs to the class of high-strength pseudo-beta titanium alloys and has the following mechanical characteristics (Table 2)[5].

Table 1 Chemical composition of lowcost titanium alloy Timetal LCB

\begin{tabular}{|l|l|l|l|l|}
\hline Ti & Mo & Fe & Al & $\mathrm{O}$ \\
\hline Base & 6.8 & 4.5 & 1.5 & 0.15 \\
\hline
\end{tabular}

Table 2 Mechanical properties of Timetal LCB

\begin{tabular}{|l|l|l|l|l|l|}
\hline $\begin{array}{l}\text { Ultimate } \\
\text { tensile } \\
\text { strength; } \\
\text { MPa }\end{array}$ & $\begin{array}{l}\text { Yield } \\
\text { strength; } \\
\mathrm{MPa}\end{array}$ & $\begin{array}{l}\text { El; } \\
\%\end{array}$ & $\begin{array}{l}\mathrm{RA} ; \\
\%\end{array}$ & $\begin{array}{l}\mathrm{KCV} ; \\
\mathrm{J} / \mathrm{cm}^{2}\end{array}$ & \\
\hline 1187 & 1166 & 13 & 40 & 3 & \\
\hline
\end{tabular}

When producing welded joints of pseudo- $\beta$ alloys by fusion welding; there are due to the high content of alloying elements in them; the crystalline structure of the $\beta$-phase of titanium and the tendency to develop chemical and physical heterogeneity in the weld metal and the HAZ. The specificity of phase and structural transformations in various parts of the welded joint caused by the thermal welding cycle; which results in a large number of metastable phases in the weld metal and HAZ; adversely affecting the mechanical properties of the welded joint; has a negative effect on the weldability of $\beta$-alloys. To reduce the formation of metastable phases; it is necessary to conduct welding with controlled cooling rates [6]. The use of preheating is one of the methods of influencing the cooling rate in a welded joint.

Therefore; the purpose of this work is to study the effect of the thermal cycle of welding when using preheating on the shape and size of the weld metal and the HAZ; as well as on the cooling rate and phase composition of the cooling metal.

Finite element modeling

For non-stationary thermal analysis with phase transition; the dependence of enthalpy on temperature was determined for the pseudo- $\beta$ titanium alloy Timetal LCB according to the Neumann-Kopp rule. In comparison with the technical titanium VT1 - 0; the heat capacity of the alloy Timetal LCB is $2 \ldots 6 \%$ less; mainly due to the low heat capacity of Fe and Mo (Fig. 1).

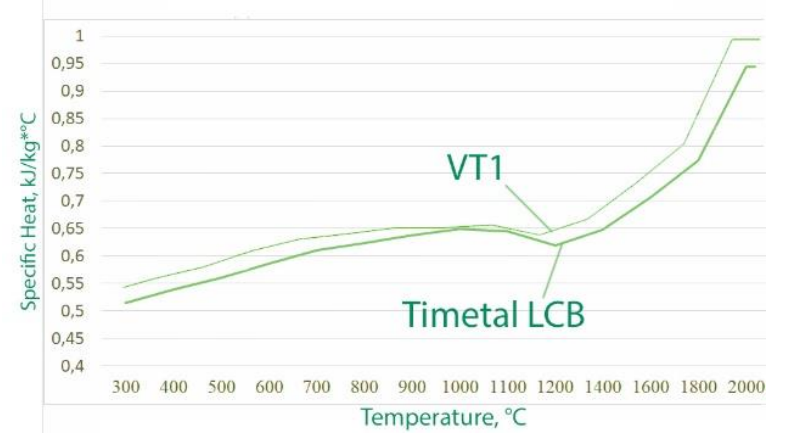

Fig. 1. Comparison of the specific heat of VT1 technical titanium and Timetal LCB economically alloyed titanium alloy.

To calculate the effect of welding mode parameters on the formation of a weld; a threedimensional mathematical model of thermal processes [7-13] in titanium was built for welding with a scanning heat source; which is based on the differential heat equation:

$\rho c\left(\frac{\delta T}{\delta t}\right)=\frac{\partial}{\partial x}\left(\lambda_{x} \frac{\partial T}{\partial x}\right)+\frac{\partial}{\partial y}\left(\lambda_{y} \frac{\partial T}{\partial y}\right)+\frac{\partial}{\partial z}\left(\lambda_{z} \frac{\partial T}{\partial z}\right)$

The simulation was performed on the sample with dimensions 200x100x10mm; for which a finite element model was constructed. The following boundary conditions are formulated; describing the heat exchange of the product with the environment [14-18] (Fig. 2).

\section{RESULTS AND DISCUSSIONS}

This model was used to simulate welding processes in titanium alloys VT23 and VT19 [19]. Comparison of the calculation results with 
experimental data confirmed the adequacy of the developed mathematical model (Fig. 3). The difference in the width of the deposited bead in the calculated and experimental sample was $3.1 \%$; the width of the return bead was $2.4 \%$.

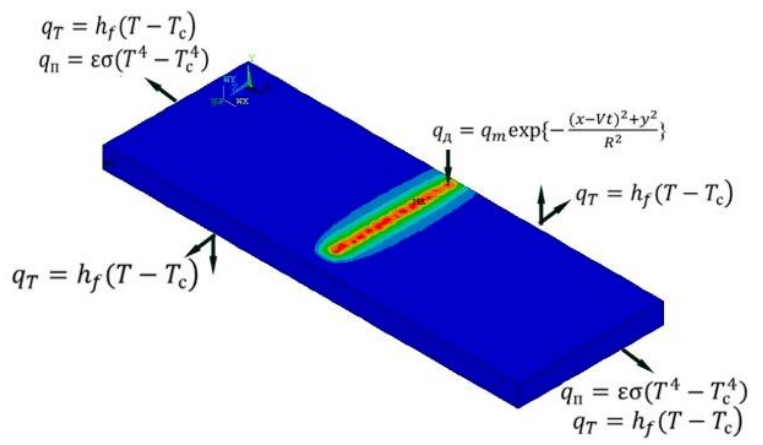

Fig. 2. Boundary conditions describing the heat exchange products with the environment.
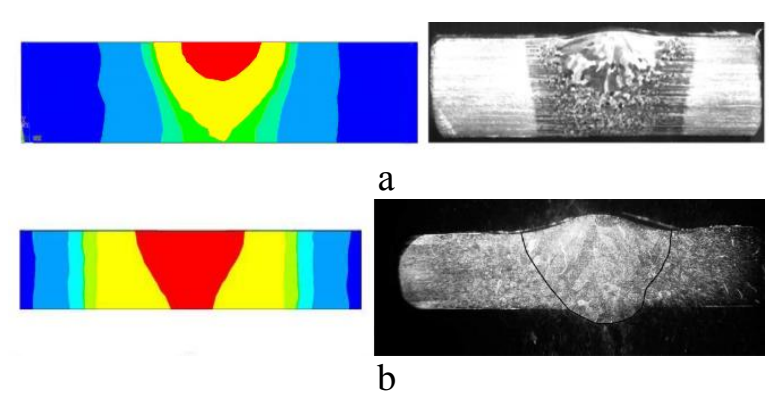

Fig. 3. Adequacy of the developed mathematical model: a - using the example of TIG welding of a two-phase high-strength titanium alloy VT23; b - using the example of the TIG welding of a pseudo$\beta$-titanium alloy VT19.

Calculations of thermal fields were carried out for 4 welding modes; with lower and higher heat input; as well as with and without using preheating (Table 4).

According to the calculation results; the isotherms of maximum temperatures were const?ucted; with the help of which the depth and width of the weld metal and the heat-affected zone were determined (Fig. 4).

Welding modes were chosen; in which the complete penetration of the weld metal was absent. This is done to determine the effect of preheating on the forum and the dimensions of the weld metal and HAZ. So; when using preheating in the mode with higher heat input (mode №2); the penetration depth increased by $17 \%$ compared to the mode without preheating (mode №1). For the regime with less heat input; the use of preheating incre?sed the penetration depth by 16\% (modes №3 and №4).

Table 4 - Modes of argon-arc welding by tungsten electrode of lowcost titanium alloy Timetal LCB; for which modelling was performed

\begin{tabular}{|c|c|c|c|c|}
\hline № & $\begin{array}{c}\text { Welding } \\
\text { current; } \\
\mathrm{A}\end{array}$ & $\begin{array}{c}\text { Welding } \\
\text { voltage; } \\
\mathrm{V}\end{array}$ & $\begin{array}{c}\text { Welding } \\
\text { speed; } \\
\mathrm{m} / \mathrm{h}\end{array}$ & $\begin{array}{c}\text { Heat } \\
\text { input; } \\
\mathrm{kJ} \\
/ \mathrm{cm}^{2}\end{array}$ \\
\hline 1 & 240 & 12 & 10 & 17280 \\
\hline 2 & 240 & 12 & 10 & 17280 \\
\hline 3 & 320 & 12 & 16 & 14440 \\
\hline 4 & 320 & 12 & 16 & 14440 \\
\hline
\end{tabular}

At the same time; the width of the HAZ when using preheating also increased (Table 5).

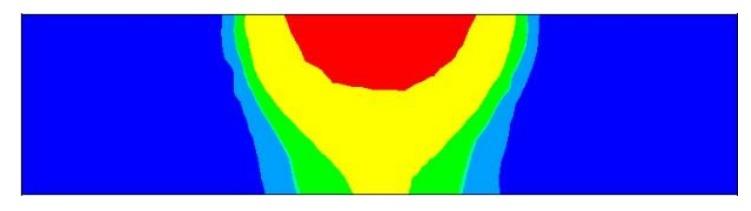

a

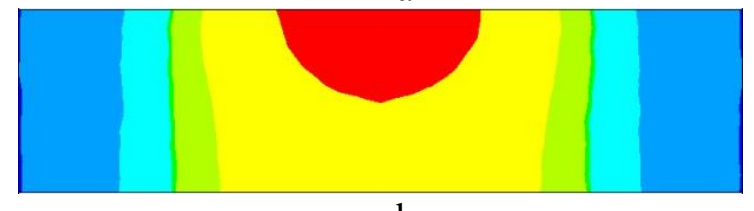

b

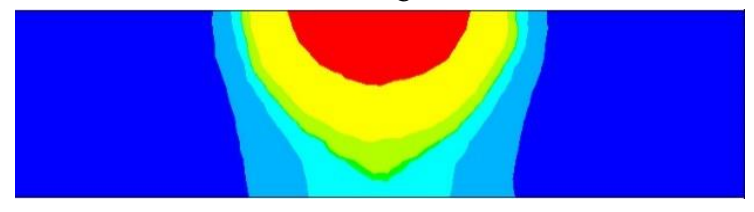

c

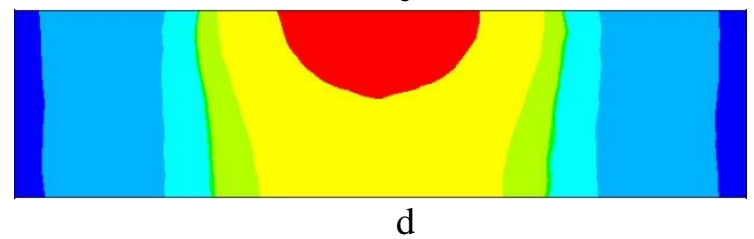

Fig. 4.The depth and width of the seam metal and heat-affected zone of welded joints of lowcost titanium alloy Timetal LCB obtained in different welding modes: a mode №1; b - mode №2; $\mathrm{c}$ - mode №3; d - mode №4.

The calculated cooling rates in the welded joint in different temperature ranges were constructed. In the temperature range of $1200 \ldots 1100^{\circ} \mathrm{C}$; high cooling rates above $200^{\circ} \mathrm{C} / \mathrm{s}$ are recorded. The 
diagram of the distribution of cooling rates (Fig. 5) shows that the cooling of the HAZ is more uniform using preheating.

Table 5. Values of penetration depth of the weld metal and the width of the heat-affected zone

\begin{tabular}{|c|c|c|}
\hline № & $\begin{array}{c}\text { Penetration } \\
\text { depth; } \mathrm{mm}\end{array}$ & $\begin{array}{c}\text { Width of } \\
\text { HAZ; } \mathrm{mm}\end{array}$ \\
\hline 1 & 4.22 & 10.81 \\
\hline 2 & 5.11 & 11.18 \\
\hline 3 & 4.02 & 9.89 \\
\hline 4 & 4.8 & 11.08 \\
\hline
\end{tabular}
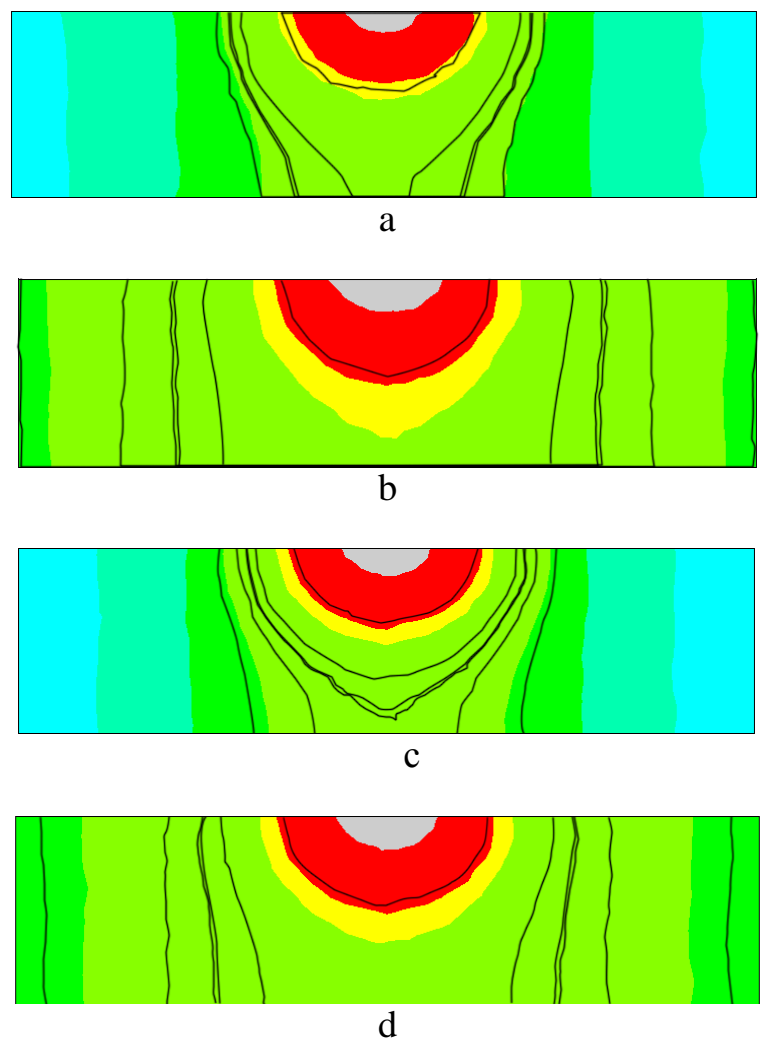

Fig. 5. Cooling speeds in temperature range 1200$1000^{\circ} \mathrm{C}: \mathrm{a}-\operatorname{mode} № 1 ; \mathrm{b}-\operatorname{mode}$ №2; $\mathrm{c}-$ mode №3; d - mode №4.

The same is observed in the temperature range of $1000 \ldots 900^{\circ} \mathrm{C}$; where cooling rates above 130 ${ }^{\circ} \mathrm{C} / \mathrm{s}$ are also recorded in all modes. Starting from the temperature range of $600 \ldots 500 \mathrm{C} / \mathrm{s}$; the cooling rates are aligned in all modes; both with and without preheating (Fig. 6).

Analyzing the obtained cooling rates; a comparative chart was drawn up (Fig. 7). The lowest values of the cooling rates can be seen to be fixed at mode 4 - using preheating during welding with a lower heat input.
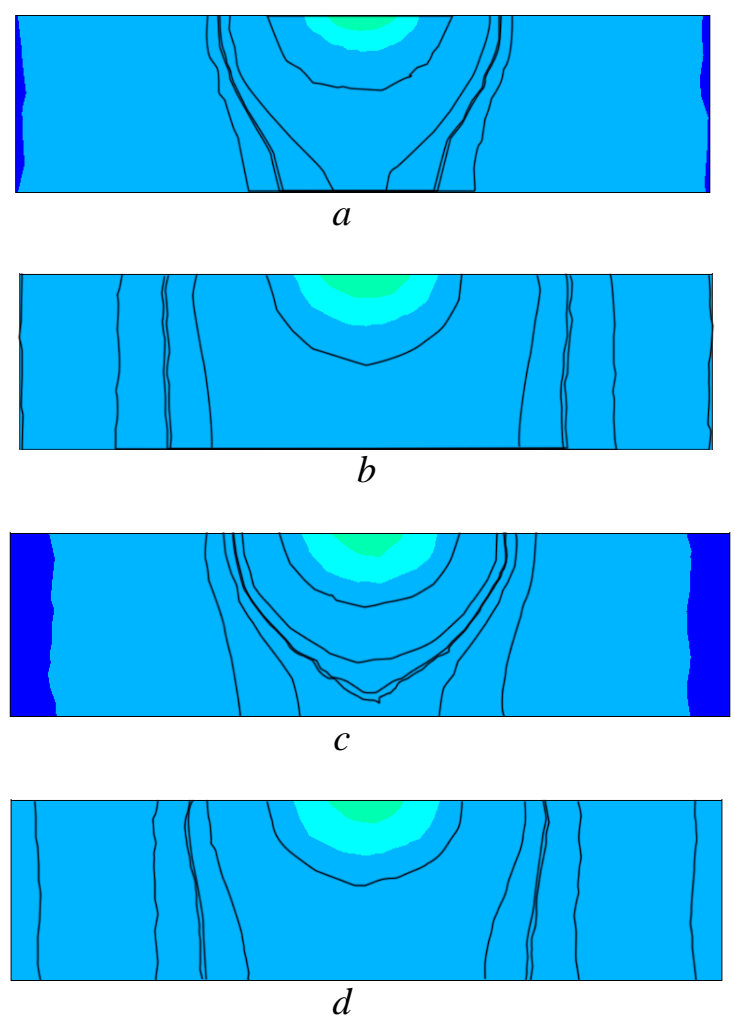

Fig. 6. Cooling speeds in temperature range 600$500^{\circ} \mathrm{C}$ : a - mode №1; $\mathrm{b}$ - mode №2; $\mathrm{c}$ mode №3; d - mode №4.

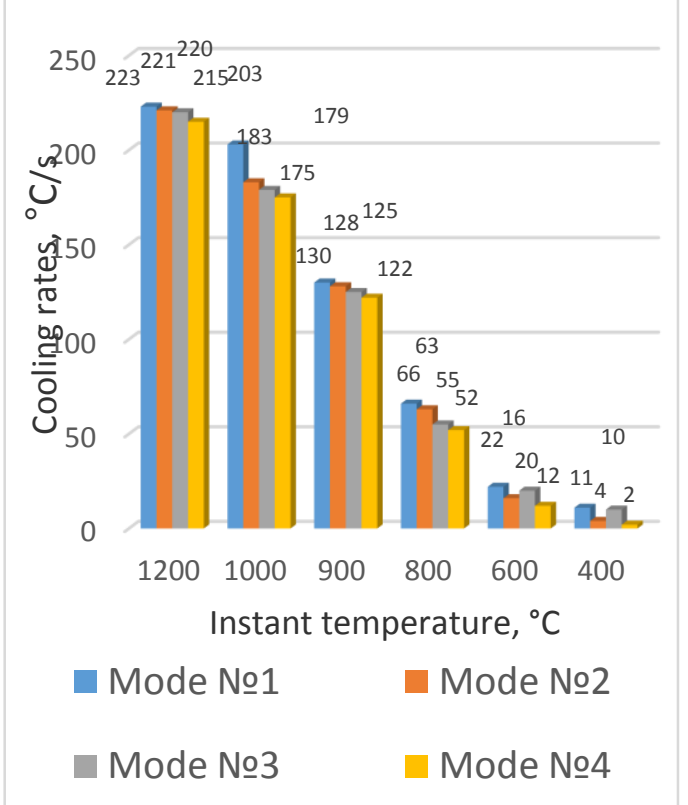

Fig. 7. Values of cooling rates in differenttemperature ranges.

Using the diagram of anisotropic transformations obtained from the literature sources (Fig. 8); one can say that in the modes without preheating with high cooling rates; a larger number of metastable phases will be fixed. With decreasing cooling rates; a greater decomposition 
of the metastable $\beta$-phase will occur along the entire length of the welded joint; resulting in a more uniform two-phase $(\alpha+\beta)$ structure; which should positively affect the mechanical properties of the welded joints.

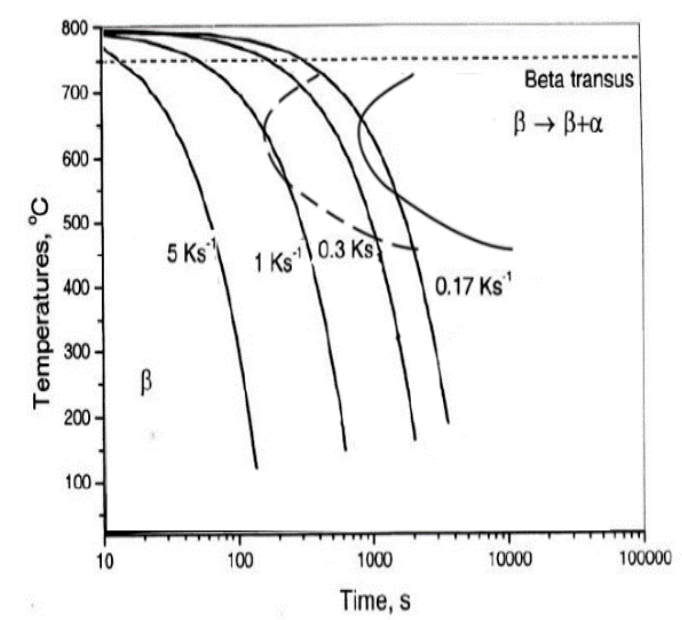

Fig. 8. Diagram of anisotropic transformations of lowcost titanium alloy Timetal LCB.

\section{SUMMARY}

1. A mathematical model of argon-arc welding with tungsten electrode of an economically alloyed titanium alloy Timetal LCB has been developed; taking into account the preheating of the welded joint to a temperature of $400^{\circ} \mathrm{C}$.

2. Based on this model; the thermal fields in the welded joint are determined. It is shown that the use of preheating leads to an increase in the depth of penetration by $16 \ldots 17 \%$; and the width of the HAZ to $10 \%$.

3. The fields of cooling rates of the welded joint were constructed; which made it possible to conclude that with the use of preheating; the cooling rate is less than without using it. Based on this; assumptions were made that when using preheating and welding in a mode with lower heat input; there will be less metastable phases in the weld metal and HAZ; and accordingly; this welded joint will have better mechanical characteristics.

\section{REFERENCES}

1. Osipenko A.V. (2015). Razrabotka tekhnologii polucheniya syr'ya dlya splavov titana iz nekonditsionnogo titana gubchatogo. Vostochno-Yevropeyskiy zhurnal peredovykh tekhnologiy; 4 (5): 28-32.
2. Kosaka Y.; Fox S. P.; Faller K.; \& Reichman S. H. (2005). Properties and processing ofTIMETAL LCB. Journal of materials engineering and performance; 14 (6): 792-798.

3. Akhonin S.V.; Belous V.Yu.; Selin R.V.; Petrichenko I.K.; Vrzhizhevskiy E.L. (2015). Struktura i svoystva svarnykh soyedineniy vysokoprochnykh dvukhfaznykh titanovykh splavov; vypolnennykh ELS i TIG. Avtomaticheskaya svarka; 8: 16-19.

4. Ibrahim K. M.; Mhaede M.; \& Wagner L. (2012). Microstructure evolution and mechanical properties of heat treated LCB titanium alloy. Transactions of Nonferrous Metals Society of China; 22 (11): 2609-2615.

5. Ivasishin O. M.; Markovsky P. E.; Matviychuk Y. V.; Semiatin S. L.; Ward C. H.; \& Fox S. (2008). A comparative study of the mechanical properties of high-strength $\beta$-titanium alloys. Journal of alloys and compounds; 457 (1-2): 296-309.

6. Akhonin S. V.; Belous V. Y.; Berezos V. A.; \& Selin R. V. (2018). Effect of TIG-welding on the structure and mechanical properties of the pseudo- $\beta$ titanium alloy VT19 welded joints in Materials Science Forum. Trans Tech Publications; 927: 112-118.

7. Gumen O.M.; Spodynyuk N.A. (2018). 3D modelyuvannya temperaturnoho prostoru pry infrachervonomu opalenni vyrobnychykh prymishchen. Visnyk Khersonskoho natsionalnoho tekhnichnoho unyversytetu; 3 (66): 137-141.

8. Gumen O.; Spodyniuk N.; Ulewicz M.; Martyn Ye. (2017). Research of thermal processes in industrial premises with energysaving technologies of heating. Diagnostyka; 2 (18): 43-49.

9. Gumen O.M.; Martyn Ye.V.; Spodyniuk N.A.; Ljaskovska S.Ye. (2017). Informatsiyni grafichni zasoby podannya prostoru temperaturnoho polya promyslovykh budivel. Visnyk Khersonskoho natsionalnoho tekhnichnoho unyversytetu; 3 (62): 269-273.

10.Khmel P.; Martyn Ye.; Ljaskovska S. (2016). Kompyuterne modelyuvannya protsesiv proektno-oriyentovanoho upravlinnya dualnymy systemamy. Visnyk Lvivskoho derzhavnoho universytetu bezpeky zhyttyediyalnosti; 14: 61-68.

11.Spodyniuk N.; Gumen O.; Omelchuk O. (2017). Thermal processes in industrial premises with using infrared heating systems. 
Journal of civil engineering; environment and architecture; 64 (4/17): 105-115.

12.Gumen O.; Spodyniuk N.; Ulewicz M.; Martyn Ye. (2017). Research of thermal processes in industrial premises with energy-saving technologies of heating. Diagnostyka; 2 (18): 43-49.

13.Gumen O.M.; Martyn Ye.V.; Spodyniuk N.A.; Ljaskovska S.Ye. (2017). Informatsiyni hrafichni zasoby podannya prostoru temperaturnoho polya promyslovykh budivel. Visnyk Khersonskoho natsionalnoho tekhnichnoho unyversytetu; 3 (62): 269-273.

14.Petras D.; Kalus D. (2000). Effect of thermal comfort/discomfort due to infrared heaters installed at workplaces in industrial buildings. Indoor and Built Environment; 9: 148-156.

15. Yurkevich Y.; Spodyniuk N. (2015). Energysaving infrared heating systems in industrial premises. Budownictwo o zoptymalizowanym potencjale energetycznym; 2 (16): 140-144.

16.Gumen O.M.; Selina I.B. (2018). Doslidzhennya heometriyi teplorozpodilu iz zaluchennyam komp'yuterno-intehrovanykh tekhnolohiy modelyuvannya. Informatsiyni systemy. Mekhanika ta keruvannya; 18: 28-33.

17.Gumen O.M.; Lebedyeva O.O. (2018). Means of graphic image of temperature field in the premises; Zbirnyk dopovidey VII Vseukrayins'koyi naukovo-praktychnoyi konferentsiyi "Prykladna heometriya; dyzayn; ob'yekty intelektualnoyi vlasnosti ta innovatsiyna diyalnist studentiv ta molodykh vchenykh»; 36-39.

18.Gumen O.M.; Yablonskyy P.M.; Shapoval S.P.; Kolomiyets N.Ya. (2018). Zasoby prostorovoho heometrychnoho modelyuvannya u doslidzhenni parametriv temperaturnoho polya prymishchennya. Suchasni problemy modelyuvannya; 12: 58-62.

19.Akhonin S.V.; Belous V.Y.; Muzhichenko A.F.; Selin R.V. (2017). Mathematical modeling of structural transformations in HAZ of titanium alloy VT23 during TIG welding. The Paton Welding; J 3: 24-27.

20.Liang X. Y.; Luo J. H.; Du H. B.; Hu X. Y.; Wu X. X.; \& Hu L. J. (2003). Comparison of heat sources in simulation of welding processes based on ANSYS [J]. Electric Welding Machine; 3.

\section{Проекція фазового складу зварних з'єднань з низькосортних титанових сплавів методом математичного моделювання скінченних елементів}

\section{Олена Гумен, Ірина Селіна, Роман Селін}

Анотація. Питанням здатності до зварювання титанових сплавів присвячено багато робіт. У зв'язку зі значною трудомісткістю експериментальних дослідів $€$ актуальним застосування математичних методів для оцінки впливу параметрів термічного циклу зварювання на структурні перетворення в металі шва та зоні термічного впливу

В дослідженні авторами розглядається новий тип функціональних матеріалів - економнолеговані титанові сплави; в яких через високий вміст легуючих елементів під час зварювання утворюється метастабільна $\beta$-фаза; що призводить до хімічної та фізичної неоднорідності у металі шва та зоні термічного впливу.

В даній роботі описується метод прогнозування фазового складу у зварному з'єднанні методом математичного моделювання на прикладі економнолегованих титанових сплавів. Цим методом розраховані теплофізичні властивості матеріалу; розраховано вплив параметрів режимів зварювання на ширину та форму зони сплавлення; зони термічного циклу зварного з'єдання та на швидкості охолодження. Метод розрахунку побудовано на основі тривимірної математичної моделі теплових процесів в титані при зварюванні; основу якого складає диференційне рівняння теплопровідності. Розрахунок проводився із застосуванням програмного забезпечення на основі методу кінцевих елементів. Адекватність розрахунків підтверджена експериментальними даними.

В ході роботи порівнювався вплив попереднього підігріву на фазовий склад зварного 3'єднання. Встановлено; що використання попереднього підігріву перед зварюванням збільшує глибину проплавлення та ширину зони термічного впливу. Попередній підігрів також зменшує швидкості охолодження в металі шва та зоні термічного циклу; що; в свою чергу; зменшить кількість метастабільних фаз у зварному з'єднанні. Це дозволить отримати зварні з'єднання з покращеними механічними властивостями; на відміну від режимів зварювання без попереднього підігріву зварних з'єднань.

Ключові слова: моделювання кінцевих елементів; теплові процеси; зварювання. 